\title{
Dose dependent reduction of erythroid progenitor cells and inappropriate erythropoietin response in exposure to lead: new aspects of anaemia induced by lead
}

\author{
W Osterode, U Barnas, K Geissler
}

\begin{abstract}
Objective-To determine whether haematopoietic progenitor cells and erythropoietin (EPO), which is an essential humoral stimulus for erythroid progenitor (BFU-E) cell differentiation, are affected by lead intoxication.

Methods-In male subjects chronically exposed to lead with and without anaemia, pluripotent (CFU-GEMM), BFU-E and granulocyte/macrophage (CFU-GM) progenitor cell counts in peripheral blood were measured with a modified clonal assay. Lead concentrations in blood (PbB) and urine (PbU) were measured by the atomic absorption technique, and EPO was measured with a modified radioimmunoassay.
\end{abstract}

Results- $\mathrm{PbB}$ in the subjects exposed to lead ranged from 0.796 to $4.4 \mu \mathrm{mol} / 1$, and $\mathrm{PbU}$ varied between 0.033 and 0.522 $\mu \mathrm{mol} / 1$. In subjects exposed to lead with $\mathrm{PbB} \geqslant 2.896 \mu \mathrm{mol} / 1 \quad(\mathrm{n}=7)$, BFU-E cells were significantly reduced $(p<0.001)$ whereas the reduction in CFU-GM cells was only of borderline significance ( $p=$ 0.037 ) compared with the age matched controls $(n=20)$. The CFU-GEMM cells remained unchanged. Furthermore, BFU-E and CFU-GM cells were reduced in a dose dependent fashion, with increasing $\mathrm{PbB}$ or $\mathrm{PbU}$, respectively. In the subjects exposed to lead EPO was in the normal range and did not increase in the presence of anaemia induced by lead. No correlations existed between EPO and $\mathrm{PbB}, \mathrm{PbU}$, or progenitor cells.

Conclusion-The data suggest new aspects of lead induced anaemia besides the currently acknowledged shortened life span of erythrocytes and inhibition of haemoglobin synthesis. Two additional mechanisms should be considered: the reduction of BFU-E cells, and inappropriate renal EPO production in the presence of severe exposure to lead, which would lead to an inadequate maturation of BFU-E cells.

(Occup Environ Med 1999;56:106-109)

Keywords: blood lead; progenitor cells; erythropoietin

Universitätsklinik für Innere

Medizin IV, Währinger

Gürtel 18-20, A-1090 Wien,

Austria. Telephone 00431

40400 4701; fax 00431

4088011 .

Accepted 17 September 1998

Anaemia in subjects exposed to lead is at present thought to be mainly caused by the inhibition of haemoglobin synthesis (basically by the inhibition of $\delta$-amionolevulinic acid dehydratase activity) and shortened life span of red blood cells. ${ }^{1-4}$ Apart from a haemolytic component, it seems likely that additional mechanisms are involved in anaemia induced by lead. The profound effect of lead on red cell precursors in bone marrow was suspected some years ago. ${ }^{1}$ An antimitotic effect of lead on erythroblast nuclei at metaphase has been shown previously. ${ }^{5}$ However, at present no in vivo data are available in regard to haematopoietic progenitor cells and exposure to lead. Such progenitor cells form colonies of haematopoietic cells in vitro which represent the differentiation of an individual precursor cell in the presence of an appropriate humoral stimulus (colony stimulating factor (CSF) or erythropoietin (EPO)). In determining the size of the total progenitor cell compartment peripheral blood progenitors have been shown to be better indicators than those in bone marrow where the concentrations depend on the variable blood dilution in bone marrow obtained by puncture. Moreover, it has been shown that there is a stable equilibrium between the pool of progenitor cells in bone marrow and that of peripheral progenitor cells. ${ }^{6}$

We therefore investigated the question whether peripheral progenitor cells or at least

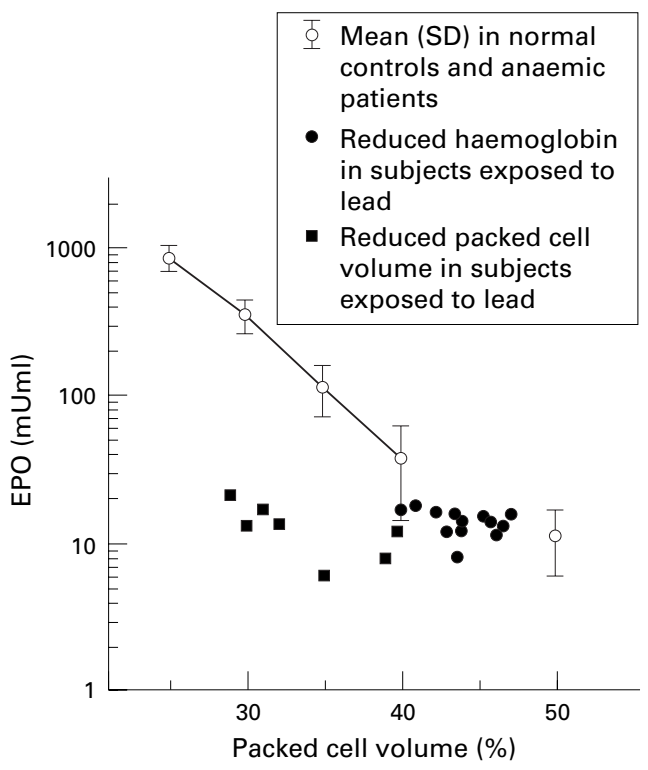

Figure 1 Serum EPO dependency on packed cell volume in subjects with no renal failure, serum EPO concentrations in subjects moderately exposed to lead, and in subjects exposed to lead with $\mathrm{PbB} \geqslant 2.896 \mu \mathrm{mol} / \mathrm{l}$. 
Table 1 Data of subjects exposed to lead $(n=20)$ and age matched controls $(n=20)$

\begin{tabular}{|c|c|c|c|c|c|}
\hline \multirow[b]{2}{*}{ Indicators } & \multicolumn{2}{|c|}{ Exposed group $(n=20)$} & \multicolumn{2}{|c|}{ Control group $(n=20)$} & \multirow[b]{2}{*}{$p$ Value } \\
\hline & Median & Range & Median & Range & \\
\hline $\mathrm{PbB}(\mu \mathrm{mol} / \mathrm{l})$ & 2.195 & $0.796-4.40$ & 0.198 & $0.145-0.676$ & 0 \\
\hline $\mathrm{PbU}(\mu \mathrm{mol} / \mathrm{l})$ & 0.225 & $0.033-0.522$ & 0.018 & $0.01-0.077$ & 0 \\
\hline Erythrocytes $\left(\times 10^{12} / 1\right)$ & 4.8 & $2.8-5.5$ & 5.1 & $4.2-5.4$ & NS \\
\hline Packed cell volume $\left(\times 10^{-2}\right)$ & 43.2 & $29-47$ & 44.2 & $41-47$ & NS \\
\hline Haemoglobin $(\mathrm{g} / \mathrm{dl})$ & 13.8 & $8.9-16.1$ & 14.9 & $13.9-16.1$ & NS \\
\hline Reticulocytes (G/l) & 56 & $31-158$ & 43 & $28-78$ & NS \\
\hline $\mathrm{EPO}(\mathrm{mU} / \mathrm{ml})$ & 13.5 & $5.6-17.2$ & 11.7 & $6.0-18.0$ & NS \\
\hline CFU-GEMM (cells/ml) & 39 & $7-127$ & 51 & $13-319$ & NS \\
\hline CFU-GM (cells $/ \mathrm{ml})$ & 269 & $83-518$ & 339 & $125-872$ & NS \\
\hline BFU-E (cells/ml) & 819 & $174-1578$ & 998 & $510-1862$ & NS \\
\hline
\end{tabular}

Table 2 Correlation coefficients $R$ (Spearman rank order) between progenitor cells in peripheral blood and blood lead $(\mathrm{PbB})$ and urinary lead $(\mathrm{PbU})$

\begin{tabular}{|c|c|c|c|c|c|c|}
\hline & \multicolumn{2}{|c|}{ CFU-GEMM (cells/ml) } & \multicolumn{2}{|c|}{ CFU-GM (cells/ml) } & \multicolumn{2}{|c|}{$B F U-E(c e l l s / m l)$} \\
\hline & $R$ & p Value & $R$ & $p$ & $R$ & $p$ Value \\
\hline $\mathrm{PbB}(\mu \mathrm{mol} / \mathrm{l})$ & -0.06 & 0.81 & -0.55 & 0.016 & -0.52 & 0.023 \\
\hline $\mathrm{PbU}(\mu \mathrm{mol} / \mathrm{l})$ & -0.16 & 0.49 & -0.68 & 0.005 & -0.66 & 0.003 \\
\hline
\end{tabular}

erythroid progenitor (BFU-E) cells are reduced in lead intoxication, and as lead has a tubulotoxic effect at a site where EPO is synthesised, ${ }^{1}$ whether EPO excretion is also affected. It was hoped that the results would help to elucidate the pathology of anaemia induced by lead.

\section{Patients and methods}

SUBJECTS

Twenty male subjects chronically exposed to lead for a mean (SD) of 46 (7) years, working in various manufacturing processes - such as smelting, casting, etc-gave their informed consent to having an additional $7 \mathrm{ml}$ blood sample taken at their regular check up for exposure to lead. Lead concentrations in blood $(\mathrm{PbB})$ and urine $(\mathrm{PbU})$ were measured as well as routine blood counts, reticulocytes, and blood chemistry. Subjects with known haema-

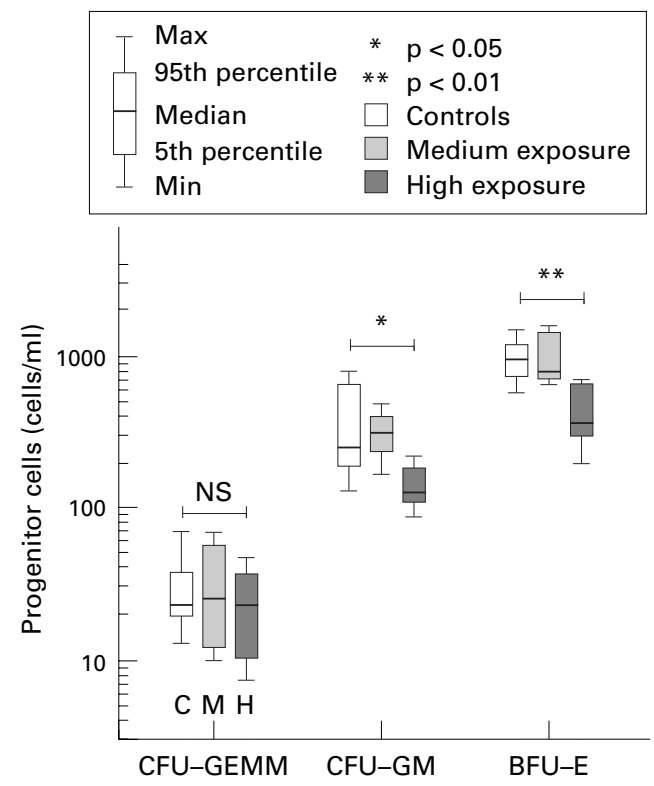

Figure 2 Progenitor cells in peripheral blood in non-exposed control subjects $(n=20)$, in subjects moderately exposed to lead $(P b B<2.896 \mu \mathrm{mol} / \mathrm{l}, n=13)$, and in subjects highly exposed to lead $(\mathrm{PbB} \geqslant 2.896 \mu \mathrm{mol} / \mathrm{l} n=7))$. tological, cardiovascular, hepatic, or renal disease were excluded.

Control data were obtained from 20 age matched healthy, non-exposed men (mean (SD) age 42 (9) years).

\section{PROGENITOR CELL ASSAY}

Pluripotent (CFU-GEMM), BFU-E, and granulocyte/macrophage (CFU-GM) progenitor cells in peripheral blood were measured with a modified clonal assay. ${ }^{78}$ Cultures were stimulated with $100 \mathrm{U} / \mathrm{ml} \mathrm{rhGM}-\mathrm{CSF}$ (Sandoz AG), 10U/ml rhIL-3 (Sandoz AG) and $1 \mathrm{mU} / \mathrm{ml}$ EPO (Toyobo, Osaka, Japan). Peripheral mononuclear cells were plated in triplicate at $2 \times 10^{5} \mathrm{ml}$. After 14 days (at $37^{\circ} \mathrm{C}, 5 \% \mathrm{CO}_{2}$, full humidity) cultures were examined under an inverted microscope. Aggregates with more than 50 translucent, dispersed cells were counted as CFU-GM cells. Bursts containing $>100$ red coloured cells were scored as BFU-E cells. CFU-GEMM cells were identified by their heterogeneous composition of translucent and haemoglobinised cells. Results are expressed as progenitor cells $/ \mathrm{ml}$ blood.

EPO ASSAY

Serum samples were stored at $-20^{\circ} \mathrm{C}$ until simultaneous measurement of EPO concentrations with a modified specific radioimmunoassay previously described. ${ }^{9}$ Concentrations of EPO in a control group $(n=25)$, ranged between 5 and $25 \mathrm{mU} / 1$ with a variance between assays $<20 \%(n=7)$ and a variance within assays $<10 \%(n=7)$.

In various anaemic patients $(n=40)$ with no renal impairment, the relation between EPO and packed cell volume was determined from a standard curve for packed cell volume between $25 \%$ and $50 \%$ (fig 1, line) for normal and anaemic patients (each $n=8$ ).

LEAD CONCENTRATIONS IN BLOOD AND URINE

The $\mathrm{PbB}$ and $\mathrm{PbU}$ were measured by atomic absorption with a Perkin Elmer 2380 spectrophotometer with a graphite furnace. ${ }^{10}$

\section{STATISTICS}

The Spearman rank order method was used to calculate the correlations. A $t$ test was used for comparisons. If the normality test used (Kolmogorov-Smirnov) failed, a nonparametric alternative (Mann-Whitney) was used. Data are represented as means (SD).

\section{Results}

Table 1 summarises haematological data, $\mathrm{PbB}$, and $\mathrm{PbU}$ for workers exposed to lead and the data from 20 aged matched subjects not exposed to lead.

No differences existed between median values of haematological variables for exposed subjects and the controls. The same applied to progenitor cells. However, in subjects exposed to lead with $\mathrm{PbB} \geqslant 2.896 \mu \mathrm{mol} / 1 \quad(n=7)$, the range in which haematological alterations are mainly expected, ${ }^{1} \mathrm{BFU}-\mathrm{E}$ cell counts were significantly reduced compared with controls $(\mathrm{n}=20)$ (484 (317) v 1027 (322), $\mathrm{p}<0.001)$, whereas CFU-GM cells only showed a border- 

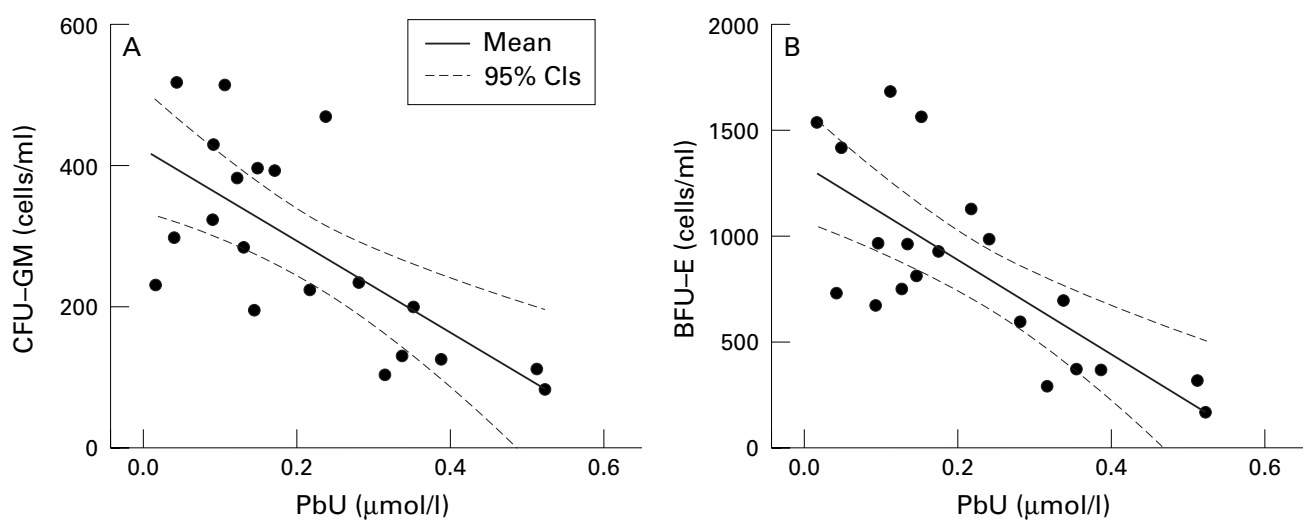

Figure 3 Dose-response relation between (A) PbU and CFU-GM and (B) PbU and BFU-E.

line reduction (163 (75) v 396 (268), $\mathrm{p}=0.034)$. The CFU-GEMM cells were not altered (fig 2). Moreover, a significant negative correlation existed between $\mathrm{PbB}$ and BFU-E or CFU-GM cells in the subjects exposed to lead. This correlation was more pronounced between $\mathrm{PbU}$ and $\mathrm{BFU}-\mathrm{E}$ or CFU-GM, respectively (table 2 and fig $3 \mathrm{~A}$ and $\mathrm{B}$ ).

Median serum EPO concentrations in the subjects exposed to lead did not differ from those in the control group (table 1). However, although EPO increased exponentially in the presence of anaemia and normal renal function (fig 1 , open circles), EPO in the subjects exposed to lead (fig 1, filled circles) failed to increase when packed cell volume or haemoglobin was reduced (filled squares). Because EPO consistently remained in the normal range, no correlations were found between $\mathrm{EPO}$ and $\mathrm{PbB}, \mathrm{PbU}$, or progenitor cells.

\section{Discussion}

We describe for the first time the effect of exposure to lead on peripheral blood progenitor cells. Our results show that BFU-E and CFU-GM cells in patients with high $\mathrm{PbB}$ are significantly reduced, and that the reduction is dose dependent.

Blood traversing the bone first passes through a surface region of rapid exchange before entering the metabolically active region of bone. After leaving the larger vessels, plasma superfusate enters the canalicules that supply bulk bone. ${ }^{11}$ Lead can thus diffuse into the total bone compartment and establish contact with bone marrow. As shown in table 2, a much higher level of significance was achieved between $\mathrm{BFU}-\mathrm{E}$ and $\mathrm{PbU}$ than between these cells and $\mathrm{PbB}$. Lead in the blood pool and that in bone are in equilibrium. ${ }^{1}$ The loss of lead by renal excretion is mainly restored by a lead fraction from bone, where lead gets into contact with bone marrow. We assume that this may be the reason why the correlation between $\mathrm{BFU}-\mathrm{E}$ and $\mathrm{PbU}$ is more significant than that with $\mathrm{PbB}$. On the other hand, the higher correlation in table 2 for $\mathrm{PbU}$ than for $\mathrm{PbB}$ could be simply due to the larger range of $\mathrm{PbU}$ values.

Recent investigations showed that progenitor cells are affected by lead. Inhibition of haem synthesis induced apoptosis in human BFU-E cells. ${ }^{12-14}$ In these experiments succiny- lactetone, a specific inhibitor of $\delta$-aminolevulinic acid dehydratase ${ }^{12}$ or isonicotinic acid hydracide, an inhibitor of $\delta$-aminolevulinic acid synthetase was used. Experiments were done on highly purified human erythroid colony forming cells (CFU-E) which differentiate from BFU-E cells. Addition of haemin to the culture medium could reverse this effect. Lead is known to be an effective inhibitor of haem synthesis in red blood cells as well. ${ }^{1}$ Although the mechanism by which the inhibition of haem synthesis produces apoptosis in progenitor cells is not clear, we assume that our results are due to apoptosis, and could thus explain a dose dependent reduction of BFU-E cells during exposure to lead. Haematological effects of lead are the only ones for which dose-response relations have been established. ${ }^{1}$ Moreover, it was shown that zinc porphyrins are potent inhibitors of haematopoiesis in animal and human bone marrow. ${ }^{15}$ Colony growth of BFU-E and CFU-GM cells was inhibited by zinc protoporphyrin. This is endogenously formed and found in high concentrations in red blood cells, in the presence of exposure to lead. It was suspected that zinc protoporphyrin may itself participate in bone marrow toxicity by lead. ${ }^{15}$

Erythropoietin is a humoral factor that stimulates the differentiation of BFU-E cells. ${ }^{16}$ Reduced EPO and increased $\mathrm{PbB}$ were found in pregnant women. ${ }^{17}$ In a group of 1502 women, analysis of variance showed that women with higher $\mathrm{PbB}$ had lower serum EPO concentrations. In our smaller group, the serum EPO values showed no difference between subjects exposed to lead and controls. However, as shown in figure 3, no increase in EPO was registered in patients with anaemia who were exposed to lead. Because the main fraction of EPO (>90\%) is produced in peritubular capillary lining cells of the kidney, ${ }^{18-20}$ we suspect that the tubulotoxicity of lead is the reason why EPO is not adequately generated at higher $\mathrm{PbB}$.

The mechanism by which lead intoxication reduces EPO is not clear, but it is suspected that lead interferes with calcium. ${ }^{19}{ }^{21}$ An increased entry of calcium into renal cells capable of producing EPO is necessary if tissue hypoxia is found. In general, it has been shown 
that lead and calcium interfere in many tissues. ${ }^{1}$ Also, electrophysiological studies have shown that lead (active from inside the erythroyctes) can mimic $\mathrm{Ca}^{2+}$ ions and activate calcium dependent potassium channels even at low concentrations. ${ }^{22}$ An impaired calcium entry may cause EPO concentrations to be reduced.

Surprisingly, we registered a decrease in BFU-E cells as well as CFU-GM cells in the presence of severe exposure to lead. Two reasons may account for this finding. Administration of EPO to patients with renal failure increased BFU-E and CFU-GM cell concentrations $^{23}$ suggesting that in vivo EPO may be a stimulator of the CFU-GM cell compartment as well. In fact, endogenous EPO concentrations in subjects exposed to lead were not increased in the presence of anaemia as expected. The second reason may be the endogenously formed zinc protoporphyrin in exposure to lead, which could also have reduced CFU-GM cells. ${ }^{15}$

A delayed blood regeneration was registered in subjects exposed to lead who had donated 0.451 blood, as shown by lower haemoglobin concentrations, erythrocyte, and reticulocyte counts 15 days after blood donation. ${ }^{24}$ This phenomenon could be explained by our results. Reduced BFU-E cell concentration and inappropriate EPO production in these subjects may account for their suspected reserve capacity for blood formation.

In conclusion, our data suggest a new aspect of lead induced anaemia. It seems that two mechanisms besides the shortened life span of red blood cells are additionally involved. They are: (a) the reduction of BFU-E cells and (b) an inappropriate secretion of EPO, which may impair the differentiation of BFU-E cells.

The skilful and excellent assistance of Ms DIJ Jäger in measuring $\mathrm{PbB}$ and $\mathrm{PbU}$ is gratefully acknowledged.

Waldron HA. The anaemia of lead poisoning: a review. $\mathrm{Br} F$ Ind Med 1966;23:83-100

2 Leikin S, Eng G. Erythrokinetic studies of the anemia of lead poisoning. Pediatrics 1963;31:996-1002.

3 Griggs RC. Lead poisoning: hematologic aspects. Progress in Hematology 1964;4:117-37.
4 Hernberg S, Nurminen M, Hasan J. Non-random shortening of red cell survival times in men exposed to lead. Enviing of red cell survival

5 Rondanelli EG, Gorini P, Colombi R, et al. Ricerche sulla patogenesi dell'anemia saturnina l'azione del piombo sulla mitosi eritroblastica. Haematologica 1958;43:1077-94.

6 Dorie MJ, Maloney MA, Patt HM. Turnover of circulating hematopoietic stem cells. Exp Hematol 1979;7:483-9.

7 Geissler K, Peschel C, Niederwieser D, et al. Potentiation of granulocyte colony-stimulating factor induced mobilisation of circulating progenitor cells by seven day pretreattion of circulating progenitor cells by seven day
ment with interleukin-3. Blood. 1996;87:2732-9.

8 Geissler K, Hinterberger W, Jäger U, et al. Deficiency of pluripotent hematopoietic progenitor cells in myelodysplastic syndromes. Blut 1988;57:45-9.

9 Ludwig H, Fritz E, Kotzman H, et al. Erythropoietin treatment of anemia associatd with multiple myeloma. $N$ Engl f Med 1990;322:1693-9.

10 Osterode W. Hemorheology in occupational lead exposure. Scand $\mathcal{F}$ Work Environ Health 1996;22:369-73.

11 O'Flaherty EL. Physiologically based models of boneseeking elements. IV. Kinetics of lead deposition in seeking elements. IV. Kinetics of lead deposit

12 Muta K, Krantz SB. Inhibition of heme synthesis induces apoptosis in human erythroid progenitor cells. $\mathcal{F}$ Cell Physiol 1995;163:38-50.

13 Ebert PS, Hess RA, Frykholm BC, et al. Succinylactetone, a potent inhibitor of heme biosynthesis: Effects on cell growth, heme content and $\delta$-aminolevulinic acid dehydratase activity in malignant murine erythroleukemia cells. Biochem Biophys Res Commun 1979;88:1382-90.

14 Muta K, Krantz SB. Apoptosis in human erythroid colonyfroming cells is decreased by stem cell factor and insulin-like growth factor I as well as erythropoietin. 7 Cell Physiol 1993;156:264-71.

15 Lutton JD, Nader GA, Drummond GS, et al. Zinc porphyrins: potent inhibitors of hematopoiesis in animal and human bone marrow. Proc Natl Acad Sci USA 1997;94:1432-6.

16 Koury MJ, Bondurant MC Maintenance by erythropoietin of viability and maturation of murine erythroid precursor cells. F Cell Physiol 1988;137:65-74.

17 Graziano JH, Slavkovic V, Factor-Litvak P, et al. Depressed serum erythropietin in pregnant women with elevated serum erythropietin in pregnant women with

18 Caro J, Erslev AJ. Biologic and immunologic erythropoietin in extracts from hypoxic whole rate kidneys and their glomerular and tubular fractions. F Lab Clin Med. 1984;103:922-31.

19 Erslev AJ, Caro J. Physiologic and molecular biology of erythropoietin. Med Oncol Tumor Pharmacother 1986;3: $159-64$

20 Goyer RA. Renal chances associated with lead exposure. In: Mahaffey KR, ed. Dietary and environmental lead: human health effects. Amsterdam: Elsevier 1985:315-38.

21 Fisher JW, Nelson PK, Beckman B, et al. Kidney control of erythropoietin production. In: Dunn MJ, ed. Renal erythropoietin production. In: Dunn MJ, ed. Renal
endocrinology. Baltimore, MD: Wiliams and Wilkins, 1983: endocrinolog.

22 Leinders T, Van Kleef RGDM, Vijverberg HPM. Distinct metal ion binding sites on $\mathrm{Ca} 2+$-activated $\mathrm{K}+$-channels in in-side-out patches of human erythrocytes. Biochim Boiphys Acta 1992;1112:75-82.

23 Geissler K, Stockenhuber F, Kabrna E, et al. Recombinant human erythropoietin and hematopoietic progenitor cells in vivo [letter]. Blood 1989;73:22-9.

24 Grandjean P, Jensen BM, Sando HS, et al. Delayed blood regeneration in lead exposure: an effect on reserve capacity. Am f Public Health 1989;79:1385-8. 